\title{
PROPOSAL TO REDUCE CONTAGION THROUGH A PROGRAMMABLE ELECTRONIC VEHICLE IN TIMES OF COVID-19
}

\author{
SIR-ALEXCI SUAREZ ${ }^{1} \&$ ALBERT MIYER SUAREZ ${ }^{2}$ \\ ${ }^{I}$ Engineering Faculty, University Francisco of Paula Santander Ocaña, Colombia \\ ${ }^{2}$ Engineering Faculty. University of Pamplona, Colombia
}

\begin{abstract}
A proposal for transporting documents between offices or areas determined by an educational institution is presented, guided by a programmable vehicle, which will help avoid person-to-person contact in daily activities, contributing to the prevention protocols of COVID-19. The vehicle travels an area of 29.7 meters per instruction, with turns at various angles. The load must not exceed $1 \mathrm{~kg}$ and the programming is by steps of $30 \mathrm{~cm}$ of linear surface. The vehicle has surface type restrictions, which should preferably be without bumps that prevent a normal trajectory. It can be programmed without the need to use a programming language, thus allowing quick implementation.

KEYWORDS: Programmable vehicle, educational institutions, COVID-19
\end{abstract}

Received: Oct 06, 2020; Accepted: Oct 26, 2020; Published: Nov 30, 2020; Paper Id.: IJMPERDOCT202078

\section{INTRODUCTION}

The World Health Organization (WHO) is a body created with the aim of improving health and making a better future in our world, with offices in more than 160 countries (OMS, 2020); officially starting work on April 7, 1948. The WHO officially reports on the outbreak of disease by the new coronavirus (COVID-19) on December 31, 2019 in Wuhan a city located in central China (OMS, 2019)Since then, the world has undergone a transformation in all its aspects, where protection and prevention measures monopolize the daily reports of each country. COVID-19 is present in most countries, and only eleven are reported without coronavirus: North Korea, Turkmenistan, Vanuatu, Samoa, Kiribati, Federated States of Micronesia, Tonga, Marshall Islands, Palau, Tuvalu, Nauru; which is undeniable to name (LaNacion, 2020).

The protocols are implemented daily to avoid contagion, and they continued to be replicated after being used in the first countries where the disease was diagnosed. Due to ignorance and the speed it spreads, publications and tests are carried out by trial and error, giving guidelines that try to help in the treatment of COVID-19. In Mexico, management protocols were given, where different treatments are analyzed according to the problem associated with COVID-19 (Pérez Nieto, Lopez, Flores Ramirez, \& Soriano, 2020), always following international guidelines. A guide for the treatment of infected people was also published (Alva et al., 2020), analyzing antimalarial, finding benefits but also adverse outcomes, giving the recommendation to carry out more tests that are effective with these treatments. In Cuba (MINSAP \& Diaz Aguila, 2020). Treatments related to the handling of corpses were published, as it is one of the forms of contagion in families. In Barcelona, protocols for dental care were published, analyzing the different treatment options according to symptoms, and preparing consultations only for emergencies, where the use of equipment with reinforced protection is recommended for auxiliary and dental personnel (Campo, 2020). In Brazil, 
the initiative was taken by a multidisciplinary group to design hospital protocols that cover diagnosis, epidemiology, prevention, transmission and protocols for doctors (De Souza et al., 2020). But asymptomatic people are not included in the protocols, forgetting that they are the ones who offer the greatest contagion and that greater control must be provided to stop the disease (Gandolfi \& Mir, 2020).

Within all the protocols, it is intended to avoid minimal contact with people, trying to get them to meet at a distance of two meters or not to visit the offices, in this way the spread can be avoided and the reuse of the masks can be avoided. (Manzano Pasquel et al., 2020). But the above is increasingly difficult to avoid, companies and staff need to be in constant production, and their production line processes cannot stop. Avoiding contact or holding closed meetings where employees from different areas visit others to complete their tasks, would help reduce contagion. The way to solve these activities without human movement is through the help of robots, used in a high range of industrial operations, where they are found among others: the automotive industry, food, contagious diseases, the aeronautical industry and care of people (EU Automation, 2020; Moreno et al., 2014; Navas Navarro, 2016). Referencing the above, one could ask if using a robot to transport documentation could reduce contact or at least prevent people from visiting several offices, with the consequences that could lead to the spread of COVID-19. There are already jobs where they specify the operation of robots to avoid personto-person contact, in cleaning and sterilization (Khan, Siddique, \& Lee, 2020). Also using a manipulator arm to allow remote evaluation and testing, combining telemedicine with telepresence (Tavakoli, Carriere, \& Torabi, 2020). Robots are also being used for the supervision of urban areas in such a way that distance and quarantine can be respected, using artificial intelligence (Chen, Marvin, \& While, 2020). In disinfection tasks they can be the solution for the purpose with which they have been created for dangerous jobs(Yang et al., 2020). But the bottom line is that they were not fully prepared for this pandemic. Robots such as Palmiche are beginning to be introduced in Latin America, which is used in a COVID-19 isolation center and its function is to bring food from the kitchen to where patients are isolated due to having the disease (OnCubaNews, 2020). The benefit of robots could also endanger employment sources, which would result in collateral damage, because after COVID-19 they could continue with the tasks in which they were already adapted (France24, 2020; Sanchez, 2020).

This research proposes the use of a programmable vehicle that can reduce the work done by people in the offices of an educational institution, in order to mitigate the spread among administrators, teachers and students, considering that a single virus carrier can carry the temporary closure of the entire institution. It is already known that most countries follow their academic activities and classes from home, in Latin America this process is almost total with the exception of Nicaragua (BID, 2020). That is why the proposal can be implemented regardless of the educational level of the institution.

\section{PROPOSED MODEL}

To simulate the transport of documents or objects between different offices or spaces in educational institutions, a Big Trak programmable electronic vehicle is used due to its robustness, easy programming and low cost (see Figure 1).The design has three stages: layout and obstacles of the grid area, design of trajectories and programming steps. In the design of the grid, the work area is measured by making a proportion of the real measurements taking them to centimeters, in the vehicle $30 \mathrm{~cm}$ are equivalent to one step; objects, workspaces and obstacles in general must be measured by means of artificial visuals or simply with surface measurements. Once the grid is developed, a mapping of trajectories is carried out with all the probabilities of distance and pauses for departure, delivery, pause and return to the end point, the algorithm used was DIjkstra (Cardona Marquez, Castrillon, \& Tinoco, 2017). The programming of the vertical movements was through $30 \mathrm{~cm}$ steps, 
where about 29.7 meters can be traveled per instruction, and the number of instructions can reach 16 with a single repetitive cycle. The turning movements can be made from 0 to 360 degrees, and in the vehicle they have different values: 90 degree movement the value is 15,360 degree movement the value is 60 .

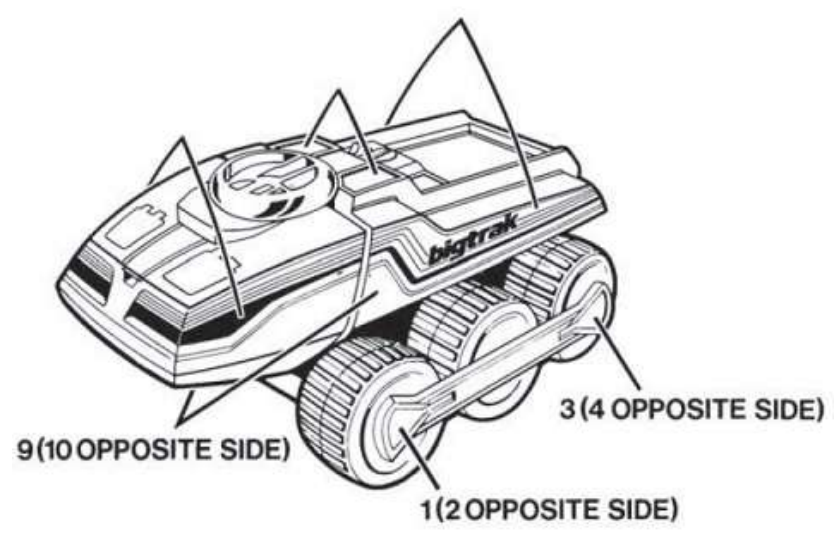

Figure 1: Programmable vehicle.

\section{Coordinates of Grids and Obstacles}

Each cell is a location or work space for the robot, and no information is collected from the environment, it is done through previous information from the work area. These grids help us to carry out the algorithm to plan the document collection and delivery routes, each of the cells has a given position in rows and columns ( $\mathrm{x}, \mathrm{y})$, and the robot takes a step on the grid which has an actual surface measurement of $30 \mathrm{~cm}$; if you go to the right 4 steps open travel 1 meter with $20 \mathrm{~cm}$ (Figure 2).

\begin{tabular}{|l|l|l|l|l|l|l|l|}
\hline 1 & 1 & 1 & 1 & 1 & 1 & 1 & 1 \\
\hline 1 & 1 & 1 & 1 & 1 & 1 & 1 & 1 \\
\hline 1 & 1 & 1 & 1 & 1 & 1 & 1 & 1 \\
\hline 1 & 1 & 1 & 1 & 1 & 1 & 1 & 1 \\
\hline 1 & 1 & 1 & 1 & 1 & 1 & 1 & 1 \\
\hline 1 & 1 & 1 & 1 & 1 & 1 & 1 & 1 \\
\hline 1 & 1 & 1 & 1 & 1 & 1 & 1 & 1 \\
\hline 1 & 1 & 1 & 1 & 1 & 1 & 1 & 1 \\
\hline 1 & 1 & 1 & ROBOT & 1 & 1 & 1 & 1 \\
\hline 1 & 1 & 1 & 1 & 1 & 1 & 1 & 1 \\
\hline 1 & 1 & 1 & 1 & 1 & 1 & 1 & 1 \\
\hline 1 & 1 & 1 & 1 & 1 & 1 & 1 & 1 \\
\hline 1 & 1 & 1 & 1 & 1 & 1 & 1 & 1 \\
\hline 1 & 1 & 1 & 1 & 1 & 1 & 1 & 1 \\
\hline 1 & 1 & 1 & 1 & 1 & 1 & 1 & 1 \\
\hline
\end{tabular}

Figure 2: Grid steps.

Although rectangular grids are represented, they can take any area according to the measurements of the areas to be covered, in the table 1 An example is shown where the distance is 3 meters and only 5 squares are made, each one measuring $60 \mathrm{~cm}$, and when programming the vehicle the instruction is to go through 5 squares and 10 steps.

Table 1: Converting measurements to steps

\begin{tabular}{|l|l|l|l|l|l|}
\hline Grid position & \multicolumn{1}{|c|}{$\mathbf{1}$} & \multicolumn{1}{|c|}{$\mathbf{1}$} & \multicolumn{1}{|c|}{$\mathbf{1}$} & \multicolumn{1}{c|}{$\mathbf{1}$} & \multicolumn{1}{c|}{} \\
\hline Robot steps & 2 & 4 & 6 & 8 & 10 \\
\hline $\begin{array}{l}\text { Real surface } \\
\text { measurements }\end{array}$ & $60 \mathrm{~cm}$ & $60 \mathrm{~cm}$ & $60 \mathrm{~cm}$ & $60 \mathrm{~cm}$ & $60 \mathrm{~cm}$ \\
\hline
\end{tabular}

Obstacles are the different objects or people that may exist in the area or the limitations of the environment such as a wall. 
In the figure 3, an administrative area is shown where the red color represents walls, the blue color divisions between offices and the orange color represents a module composed of a person and a work table. The task consists of collecting documents at point $\mathrm{A}$ and taking them to $\mathrm{B}$, pausing for 1 minute and then returning to the starting point, this would prevent a person from having to move, with the consequences that could have for the spread of the virus, of course, the preventive measures at each point when sharing documents must be predictable with sterilization protocols for them.

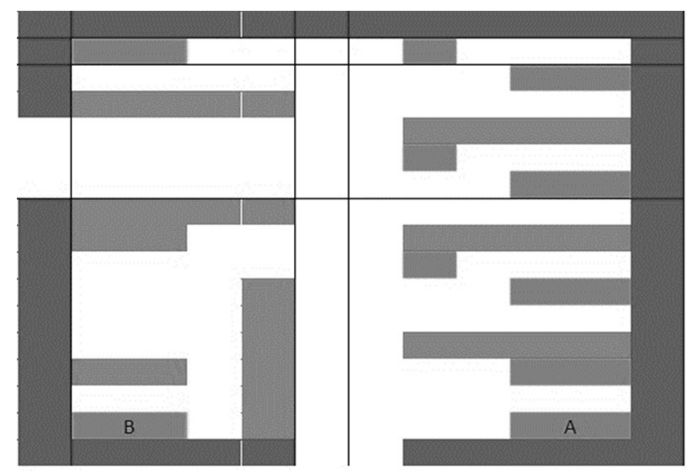

Figure 3: Obstacle area, collection and delivery point.

\section{Route planning}

Routes can be planned according to horizontal and vertical movements, movements according to degrees, and waiting pauses to pick up or deliver. The programming of the horizontal and vertical routes are carried out following the movement instructions and then the number of steps per measure, in the Figure 4 you can see the vertical path keys up and down, which are programmed only with the number of steps to follow according to the measure to be traveled.

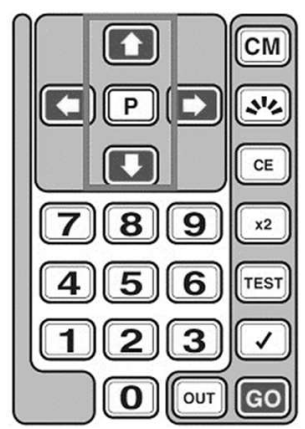

Figure 4. Path control knob

If you want to make turns, use the left and right keys with their respective value of degrees to turn according to the values of the Figure 5. When we want to turn right, we must first program the movement and then the value of 15 degrees with which the vehicle will turn to the right, the value of degrees can be changed if we go to the right or left to reduce the amount of movement, if a full 360 degree turn is desired, for the vehicle the value is 60 degrees. 

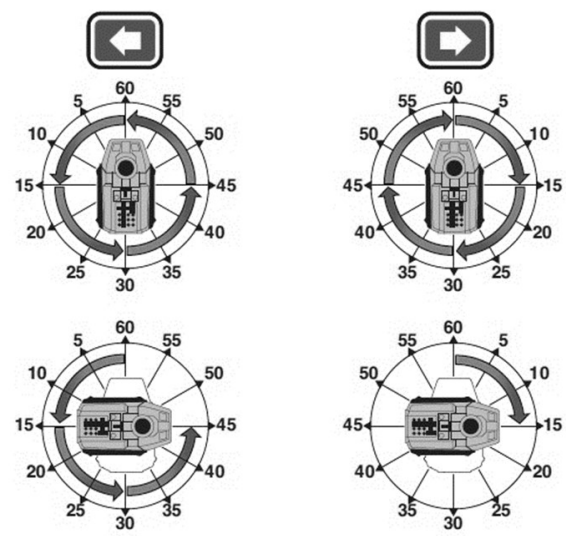

Figure 5: Conversion of degrees

\section{Motion modeling}

To model the routes, an algorithm based on free and occupied spaces is used, the algorithm connects cells and creates connections according to the grid designed in the planning of spaces, so it creates a route sheet with the least amount of steps to program, as well as the smallest distance, creating a logical matrix with the movements originated from the initial matrix of the grid

\section{Document transfer simulation}

The simulation consists of going from point A to B (see figure 6), and a route has been programmed following turns with a value of 15 vehicle degrees and vertical movements. The vehicle must carry the package and wait 1 minute and then return to the starting point; all work zones and divisions are obstacles to the vehicle's program, so that it can generate the appropriate routes.

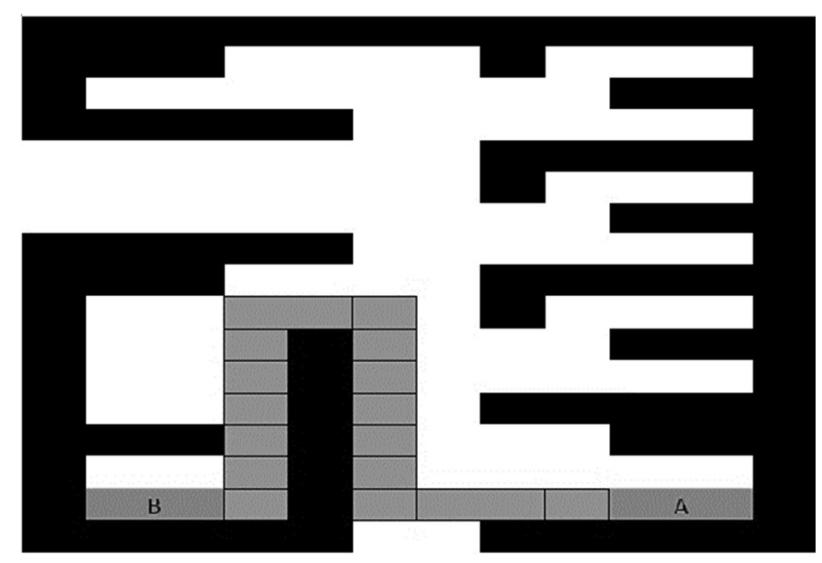

Figure 6: Document delivery simulation

The steps to follow are shown in the programming of the table 2, you only have to follow the grid according to each movement, which is quick to program and the vehicle can be put into operation in a short time for the transport of documents or objects. 
Table 2: Route programming.

\begin{tabular}{|c|c|c|c|c|c|c|}
\hline Up & Down & Left & Right & Pause & Start & Travel \\
\hline & & & & & Press & \\
\hline \multicolumn{7}{|l|}{ Press } \\
\hline \multicolumn{7}{|l|}{4 steps } \\
\hline & & & Press & & & \\
\hline & & & 15 degree & & & \\
\hline \multicolumn{7}{|l|}{ Press } \\
\hline \multicolumn{7}{|l|}{6 steps } \\
\hline & & Press & & & & \\
\hline & & 15 degree & & & & \\
\hline \multicolumn{7}{|l|}{ Press } \\
\hline \multicolumn{7}{|l|}{2 steps } \\
\hline & & Press & & & & \\
\hline & & 15 degree & & & & \\
\hline \multicolumn{7}{|l|}{ Press } \\
\hline \multicolumn{7}{|l|}{6 steps } \\
\hline & & & Press & & & \\
\hline & & & 15 degree & & & \\
\hline \multicolumn{7}{|l|}{ Press } \\
\hline \multicolumn{7}{|l|}{1 steps } \\
\hline & & & & Press & & \\
\hline & & & & 400 (parcel delivery pause) & & \\
\hline & & Press & & & & \\
\hline & & 60 degrees & & & & \\
\hline \multicolumn{7}{|l|}{ Press } \\
\hline \multicolumn{7}{|l|}{1 steps } \\
\hline & & Press & & & & \\
\hline & & 15 degree & & & & \\
\hline \multicolumn{7}{|l|}{ Press } \\
\hline \multicolumn{7}{|l|}{6 steps } \\
\hline & & & Press & & & \\
\hline & & & 15 degree & & & \\
\hline \multicolumn{7}{|l|}{ Press } \\
\hline \multicolumn{7}{|l|}{2 steps } \\
\hline & & & Press & & & \\
\hline & & & 15 degree & & & \\
\hline \multicolumn{7}{|l|}{ Press } \\
\hline \multicolumn{7}{|l|}{6 steps } \\
\hline & & Press & & & & \\
\hline & & 15 degree & & & & \\
\hline \multicolumn{7}{|l|}{ Press } \\
\hline $\begin{array}{l}4 \text { steps (return to } \\
\text { starting position) }\end{array}$ & & & & & & \\
\hline & & & & & & Press \\
\hline
\end{tabular}

\section{CONCLUSIONS}

The programmable vehicle can travel long distances taking turns and pauses to carry and deliver documentation in open or closed space office areas, with quick programming without coding knowledge. The proposal avoids the transfer and contact from person to person as a protocol to prevent the spread of the coronavirus in educational institutions exposed to students, teachers and administrators. The vehicle has surface type restrictions, which should preferably be without bumps that prevent a normal trajectory. 
For future works, the use of several vehicles in operation is intended, with routes through controllers that allow greater logistics avoiding possible collisions in trajectories.

\section{REFERENCES}

1. Alva, C., Velásquez-Rimachi, V., Morán-Mariños, C., Osores-Flores, M., Huerta Rosario, A., Molina Niño de Guzmán, R., Chachaima Mar, J. (2020). Guias de tratamiento para los pacientes infectados con COVID-19. Medicina Interna de Mexico, 36, 509-529. https://doi.org/10.24245/mim.v36i4.4271

2. BID. (2020). La educación en tiempos del coronavirus: Los sistemas educativos de América Latina y el Caribe ante COVID-19 | Publications. Recuperado 12 de octubre de 2020, de https://publications.iadb.org/publications/spanish/document/Laeducacion-en-tiempos-del-coronavirus-Los-sistemas-educativos-de-America-Latina-y-el-Caribe-ante-COVID-19.pdf

3. Campo, N. (2020). INFOGRAFIA COVID-19: PROTOCOLO ATENCIÓN DENTAL.

4. Cardona Márquez, M., Castrillón, O., \& Tinoco, H. (2017). Determinación del Método Óptimo de Operaciones de Ensamble Bimanual con el Algoritmo de Dijkstra (o de Caminos Mínimos). Informacion Tecnologica, 28, $125-134$. https://doi.org/10.4067/S0718-07642017000400015

5. Chen, B., Marvin, S., \& While, A. (2020). Containing COVID-19 in China: AI and the robotic restructuring of future cities. Dialogues in Human Geography, 10(2), 238-241. https://doi.org/10.1177/2043820620934267

6. De Souza, T., Vieira, G., Bitencourt, G., Silva, Í, Pereira, I., Costa, L., ... De Souza, R. F. (2020). PROTOCOLOS HOSPITALARES PARA O ENFRENTAMENTO DA COVID-19.

7. EU Automation. (2020). Los diferentes tipos de robots empleados para automatizar la fabricación. Recuperado 13 de octubre de 2020, de http://www.automaticaeinstrumentacion.com/es/notices/2020/07/conozca-a-sus-robots-46860.php

8. France24. (2020). Ciencia y Tecnología-Covid-19: Los robots podrían poner en jaque a miles de trabajadores en el mundo. Recuperado 13 de octubre de 2020, de France 24 website: https://www.france24.com/es/20200523-robots-pondría-en-jaquetrabajadores

9. Gandolfi, A., \& Mir, J. (2020). Asintomáticos Covid 19, excluidos de protocolos. Atención Primaria. https://doi.org/10.1016/j.aprim.2020.06.005

10. Khan, Z. H., Siddique, A., \& Lee, C. W. (2020). Robotics Utilization for Healthcare Digitization in Global COVID-19 Management. International Journal of Environmental Research and Public Health, 17, 1-23. https://doi.org/10.3390/ijerph17113819

11. LaNacion. (2020). Países sin coronavirus registrado en su territorio hasta el 12 de octubre. Recuperado 13 de octubre de 2020 , de La Nación, Grupo Nación website: https://www.nacion.com/el-mundo/paises-sin-coronavirus-registrado-en-suterritorio/3I2FS6H2HNGABAEIZKXATE4KGM/story/

12. Manzano Pasquel, A., Escalante, S., Zabala, A., Moreno, A., Sánchez, X., Perez-Pazmino, F., \& Jimbo Sotomayor, R. (2020). Reutilización de mascarillas N95.

13. MINSAP, \& Diaz Aguila, H. (2020). Protocolo vs COVID-19. MINSAP Cuba.

14. Moreno, H. A., Saltarén, R., Puglisi, L., Carrera, I., Cárdenas, P., \& Álvarez, C. (2014). Robótica Submarina: Conceptos, Elementos, Modelado y Control. Revista Iberoamericana de Automática e Informática Industrial RIAI, 11(1), 3-19. https://doi.org/10.1016/j.riai.2013.11.001

15. Navas Navarro, S. (2016). Smart robots y otras máquinas inteligentes en nuestra vida cotidiana. Recuperado de 
https://ruidera.uclm.es/xmlui/handle/10578/23525

16. OMS. (2019). Nuevo coronavirus 2019. Recuperado 13 de octubre de 2020, de https://www.who.int/es/emergencies/diseases/novel-coronavirus-2019

17. OMS. (2020). OMS | Quiénes somos y qué hacemos. Recuperado 13 de octubre de 2020, de WHO website: http://www.who.int/about/es/

18. OnCubaNews. (2020). Palmiche, el robot cubano que trabaja en un centro de aislamiento para Covid-19. Recuperado 13 de octubre de 2020, de NODAL website: https://www.nodal.am/2020/06/palmiche-el-robot-cubano-contra-el-covid-19/

19. Pérez Nieto, O., López, E. I., Flores Ramirez, R., \& Soriano, R. (2020). PROTOCOLO MANEJO COVID-19. 43-52. https://doi.org/10.35366/93280

20. Sanchez, J. M. (2020). Drones, robots y aplicaciones: Tecnologías al servicio de la lucha contra el coronavirus. Recuperado 13 de octubre de 2020, de Abc website: https://www.abc.es/tecnologia/informatica/soluciones/abci-drones-robots-y-aplicacionestecnologias-servicio-lucha-contra-coronavirus-202003260232_noticia.html

21. Tavakoli, M., Carriere, J., \& Torabi, A. (2020). Robotics For COVID-19: How Can Robots Help Health Care in the Fight Against Coronavirus.

22. Yang, G.-Z., Nelson, B. J., Murphy, R. R., Choset, H., Christensen, H., Collins, S. H., ... McNutt, M. (2020). Combating COVID19 - The role of robotics in managing public health and infectious diseases. Science Robotics, 5(40). https://doi.org/10.1126/scirobotics.abb5589 